International Journal of Instruction e-ISSN: 1308-1470 • www.e-iji.net

Article submission code 20201231225908

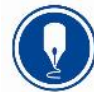

January $2022 \bullet$ Vol.15, No.1

p-ISSN: 1694-609X

pp. $277-292$

Received: $31 / 12 / 2020$

Revision: 22/06/202
Accepted: 16/07/2021

OnlineFirst: 24/10/2021

\title{
Science Teachers' Views on the Use and Effectiveness of Interactive Simulations in Science Teaching and Learning
}

\section{Mhamed Ben Ouahi}

Ibn Toufail University Faculty of science Kenitra, Morocco, mhamed.benouahi@uit.ac.ma

\section{Driss Lamri}

Regional center of education and training Rabat/Kenitra, Morocco, lamridriss11@gmail.com

Taoufik Hassouni

Regional center of education and training Fes/Meknes, Morocco, taoufik.hassouni@uit.ac.ma

El Mehdi Al Ibrahmi

Ibn Toufail University Faculty of science Kenitra, Morocco,

alibrahmielmehdi@yahoo.fr

The objective of this article is to identify and discuss the views of teachers of physics-chemistry (Ph-Ch) and Life and Earth Sciences (LES) on the use and effectiveness of interactive simulations PhET (Physics Education Technology) in student teaching and learning. A survey research method was used in this study. 114 Moroccan science teachers (67 Ph-Ch; 47 LES) at middle and high schools were surveyed. The quantitative analysis was performed to provide insight into who uses PhET simulations, why they use them, and how they are used. The data collected was analyzed using Statistical Package for the Social Sciences (SPSS) software. The results indicate that the use of interactive simulations in investigative science teaching and learning is very effective for both teachers and students, despite the presence of a set of obstacles that hinder the use of classroom simulations. The implication of this research is that the use of interactive simulations in science teaching in Morocco can enhance learning activities and help students to understand scientific concepts effectively.

Keywords: science learning, interactive simulation, PhET, teacher views, effectiveness, obstacles

\section{INTRODUCTION}

Educational techniques are one of the basic pillars of the educational learning process. They represent an integral part of the global educational system, because the challenges

Citation: Ben Ouahi, M., Lamri, D., Hassouni, T., \& Al Ibrahmi, E. M. (2022). Science teachers' views on the use and effectiveness of interactive simulations in science teaching and learning. International Journal of Instruction, 15(1), 277-292. https://doi.org/10.29333/iji.2022.15116a 
facing the world and the rapid changes in all areas of life have forced educational institutions to adopt Information and Communication Technologies (ICT) and its latest developments to achieve its objectives according to the educational system. In this sense, Morocco, like all developing or Western countries, has understood the importance of the use and integration of ICT in its education system (Mastafi, 2013). Therefore, an ambitious national program is being implemented, such as the program for the Generalization of Information and Communication Technologies in Education in Morocco GENIE (launched in early 2006 and revised in 2009) in application of the high royal instructions and in accordance with the provisions of the National Charter of Education and Training (MEN, 2002) in its levers 10 and 11. ICT is also part of the emergency plan 2009-2013 and the strategic vision of the 2015-2030 reform which aims in its twelfth project to strengthen the integration of educational technologies to improve the quality of learning, the integration of digital media and interactive tools in teaching and learning activities as well as research and innovation (CSEFRS, 2015). The use of interactive simulations in the science education curriculum is also part of these guidelines.

The interactive simulation that can be used in science education is PhET (Physics Education Technology). The PhET project (http://phet.colorado.edu) was developed by the University of Colorado at Boulder (K. Perkins et al., 2012). This site provides free learning simulations in physical science, mathematics, chemistry, biology, and earth sciences that can be downloaded for the benefit of classroom instruction or that can be used for individual learning (Sinulingga et al., 2016). These learning simulations are also compatible with various learning objectives, implementation contexts, pedagogical approaches, grade levels and learners.

The Simulations interactive PhET helps teachers and students to see something that is not visible such as atoms, electrons, photons, and electric fields (C E Wieman et al., 2013). They may also provide a common depiction between students and teachers who are facilitating all communications and instructions. PhET simulations offer teachers multiple opportunities to develop rich learning activities. Their main quality is to encourage students to use them with minimal guidance to explore physical phenomena. They have been specifically designed to achieve this objective (Carl E. Wieman \& Perkins, 2006).

The simulations PhET can replace experiments that are difficult to control, dangerous, or impossible to perform in the laboratory, such as working with nervous systems, lightning, or dynamite (Ndihokubwayo, 2017).The advantages of this simulations are that they give students the opportunity to interact with dynamic visuals, focus on exploring inquiry, provide fast feedback and experience using multiple representations (Moore et al., 2013) . Thus, PhET simulation can be used as a solution to improve students' creativity in natural science lesson (Astutik \& Prahani, 2018). Student problem-solving skills are influenced by the type of approach used through inquirybased learning with PhET simulation (Yuliati et al., 2018).

This simulation is an effective method for teaching concepts, activities, and experiments due to its flexibility and vitality, especially in various scientific fields, such as physics 
and earth science, which are difficult to teach based on usual methods (K, 2017). Interactive simulations also help transfer the effect of learning to other situations and apply it in similar situations in working life (K. Perkins et al., 2012). In addition, interactive simulations reduce the time and effort required to conduct experiments compared to realistic laboratories (Roschelle et al., 2000).

The integration of interactive simulations in the educational space can activate multiple skills in science learners such as observing, measuring, predicting, controlling variables, formulating hypotheses and interpreting results (Droui \& El Hajjami, 2014; Mahdi \& Laafou, Mohamed.R, 2018). It allows learners to explicitly develop metacognition and allows them to reflect on their learning (Droui \& El Hajjami, 2014), it also improves classroom motivation and interest (Martinez-Jimenez et al., 2003; Stéphane \& Ze, 2018), and presents itself as an effective predictive tool (Lavoie \& Good, 1988). On the other hand, the simulation based on the investigative approach is able to help students overcome their learning difficulties and partially solve a problem of widespread misconceptions (Jemaa \& Boilevin, 2016).

Several studies have investigated the effectiveness of computer simulations in science teaching and learning. (Bell \& Smetana, 2008; Rutten et al., 2012) have found that the use of simulations can improve teaching effectiveness. In addition, (Dega et al., 2013) showed that in the abstract conceptual domains of electricity and magnetism, cognitive perturbation strategies through interactive simulations are more effective than cognitive conflict strategies through interactive simulations in facilitating conceptual change.

Internationally, a number of researches have focused on teachers' views on the use of interactive simulations in science education (Physics, Life and Earth Sciences). Science teachers (high schools, middle schools) who are using PhET in their lessons report that PhET simulations are flexible tools used by a wide range of educators with a variety of student populations to shore a wide range of pedagogical objectives and use a variety of pedagogical approaches (K. K. Perkins et al., 2015). Similarly, a study(Price et al., 2018) examined a 2000 responses from secondary teachers on how they used interactive PhET simulations and the value they considered as students. This study showed that teachers valued flexibility. They used more simulations to achieve various learning objectives (understanding content, scientific process, and motivation).

However, Several researches find that teachers have difficulties in integrating technology into their lessons (Erdem, 2019; Ghavifekr \& Rosdy, 2015; Proctor et al., 2013), due to current lack of materials in schools, lack of consultant staff to guide teachers, insufficient professional development in the field of technology, complaints about time pressure due to teachers' inability to manage time effectively and teachers' lack of competence in information technology, and pressing concern about whether the use of interactive simulation can directly contribute to test scores (Bo et al., 2018).

Although studies such as (Ben Ouahi et al., 2021; Droui \& El Hajjami, 2014; Mahdi \& Laafou, Mohamed.R, 2018; Nafidi et al., 2018) can be found in the Moroccan literature on the use of interactive simulations in science education, there are no studies on this topic covering the views of science teachers on the use and effectiveness of interactive simulations in teaching. This research was conducted to address this gap in the 
literature. The effective use of interactive simulations in science classes has gained importance since students have difficulty in learning science subjects. Therefore, the purpose of this research is to determine the views of physics and life and earth science teachers on the use of simulations to enhance teaching in middle schools and high schools, and to identify factors that may hinder this use by asking the following questions:

1.What are teachers' views on the effectiveness of using simulations in science?

2.What are the types of approaches used by teachers when using interactive simulations in their classrooms?

3. What are the main obstacles hindering the use of interactive PhET simulations in the classroom?

\section{METHOD}

\section{Research design}

In this research, we used quantitative methodology to collect and analyze the data from all the respondents. The questionnaire was developed and finalized before being shared with the participants. The aim of this research is to explain the current state of simulation interactive integration in Moroccan science teaching from the science teacher's perspective. This design allows us to evaluate the views of science teachers as a first step toward understanding why simulations are used in science teaching and learning.

\section{Participants}

The overall total of respondents for this research consisted of 114 teachers in the physics-chemistry and life and earth sciences disciplines who use interactive simulations in their classrooms. Table 1 provides general information on the responding teachers.

Table 1

General information on the responding teachers

\begin{tabular}{|c|c|c|c|}
\hline Factors & & Frequency & Percentage (\%) \\
\hline \multirow{2}{*}{ Gender } & Female & 34 & 29,82 \\
\hline & Male & 80 & 70,18 \\
\hline \multirow{3}{*}{ Age } & Between [23 and 33 years old] & 52 & 45,61 \\
\hline & Between [34 and 43 years old] & 23 & 20,18 \\
\hline & [Over 43 years old [ & 39 & 34,21 \\
\hline \multirow{2}{*}{ Subject taught } & $\mathrm{Ph}-\mathrm{Ch}$ & 67 & 58,77 \\
\hline & LES & 47 & 41,23 \\
\hline \multirow{2}{*}{ Type of School } & Middle school & 69 & 60,53 \\
\hline & $\overline{\text { High school }}$ & 45 & 39,47 \\
\hline \multirow{5}{*}{$\begin{array}{l}\text { Teaching } \\
\text { Experience }\end{array}$} & $<5$ years & 26 & 22,81 \\
\hline & [5-10] years & 31 & 27,19 \\
\hline & ]10-15] years & 21 & 18,42 \\
\hline & ]15-20] years & 11 & 9,65 \\
\hline & $>20$ years & 25 & 21,93 \\
\hline \multirow{3}{*}{ School Area } & Urban & 67 & 58,77 \\
\hline & Semi-urban & 28 & 24,56 \\
\hline & Rural & 19 & 16,67 \\
\hline
\end{tabular}


In the total population $(\mathrm{n}=114)$ based on gender, there are 80 men respondents with a percentage of $70.18 \%$ versus only 34 women with $29.82 \%$. The population of our study is formed mainly of young teachers: $52(45.61 \%)$ have an average age of less than 33 years, $23(20.18 \%)$ have an average age between 34 years and 44 years and only 39 $(34.21 \%)$ are over 45 years old. Among the overall respondents based on the subject taught, there are $67(58.77 \%)$ respondents who teach the subject physics-chemistry compared to the subject life and earth science with 47 (41.23\%). From the total population based on type of school, there are $45(39.47 \%)$ respondents who are teaching in high school as compared to middle school $69(60.53 \%)$. The teaching experience of the teachers in our survey who responded to our questionnaire was very heterogeneous, $57(22.81 \%+27.19 \%=50 \%)$ are less than 10 years old, only 25 (21.93\%) have more than 20 years of seniority. This indicates that our population is young. Of the total population based on the school area, more respondents are teaching in the urban and semi-urban school area with $95(83.33 \%)$ as compared to respondents who are teaching in the rural school area with $19(16.67 \%)$.

\section{Instrument}

In this study, we used a survey questionnaire (30 items) developed and validated by three experts (two science teachers with long experience in teaching and one educational inspector). The aim of this instrument is to explore science teachers' views on the effectiveness and integration of interactive simulations in the learning of Life and Earth Sciences (LES) - Physics and Chemistry (Ph-Ch) in high and middle school and their effect on student learning. The questionnaire consists mainly of four sections: the first section deals with respondents' personal data and includes 6 items that include gender, age, teaching experience, the subject they teach, the type of school, and the school area. The second section consists of 2 items that address the type of approach teachers follow when using simulations and the timing of their use. The third section consists of 12 items on teachers' opinions of the use of simulations in the classroom and their effects on student learning. The fourth section consists of 9 items that examine the obstacles that hinder the use of simulations in the classroom. Six-Likert-scale (ranged from $6=$ Strongly Disagree, 5 = Disagree, $4=$ Slightly Disagree, $3=$ Slightly Agree, $2=$ Agree, and $1=$ Strongly Agree) has been used in third section. We used closed-ended questions in the first, second, and fourth sections because they are easier to analyze, as each answer can be assigned a number or value, allowing the statistical meaning to be evaluated. Regarding the reliability of the internal consistency, the Cronbach's alpha value was found to be 0.904 , which shows that the reliability is excellent $(\alpha \geq 0.9)$ (Taber, 2018).

\section{Procedure and Data Collection}

After developing and validating the questionnaire, we shared it randomly online (Facebook, WhatsApp, Telegram) using the Google-Forms tool with Moroccan science teachers (physics-chemistry and life and earth sciences), who use interactive simulations in their teaching. The data was collected within 2 weeks (July 2020) through random sharing. The data collected from the respondents was analyzed using Statistical Package for the Social Sciences version 23. Descriptive statistics analysis using frequency, 
percentage, mean, and standard deviation was used to analyze the data collected from the questionnaire.

\section{FINDINGS}

Science teachers' views regarding the use and effectiveness of simulations in science education, and factors that hinder their use are presented in the tables (2 to 4 ) and figures $(1,2$ and3) below. Participants' responses to each questionnaire statement are also presented.

\section{The types of pedagogical approaches that teachers follow when using simulations and the timing of their use.}

Analysis of the data collected on the multiple-choice question "What type of approach do you take when using simulations in the classroom" shows that most teachers implement interactive simulations in various ways in their classrooms (Table 2, Figure 1). Almost two thirds of respondents $64 \%$ use the investigative approach when using simulations, while $22.8 \%$ use the deductive approach and the rest of the teachers $13.2 \%$ use the inductive approach.

Table 2

Type of approach, time of use of the simulations

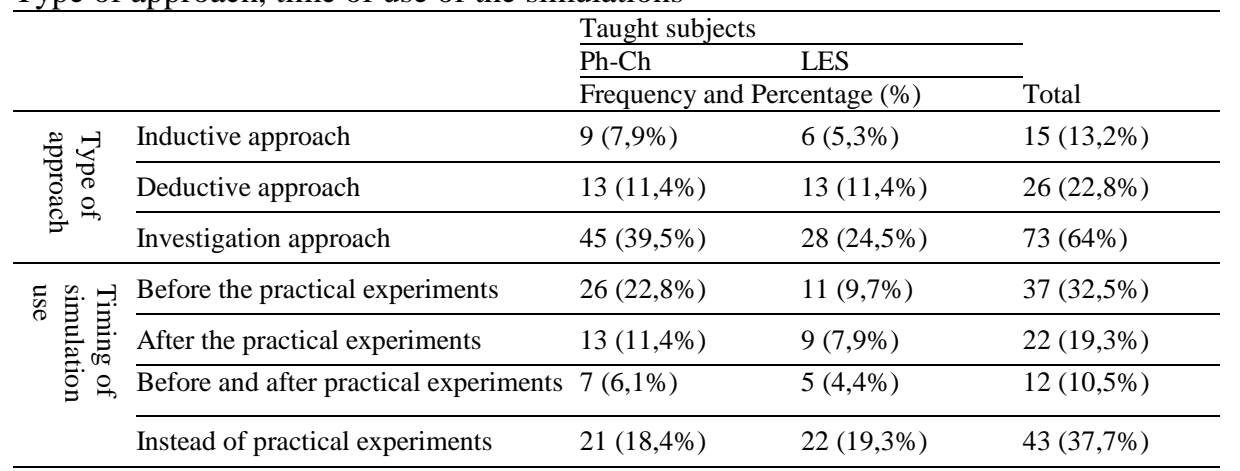

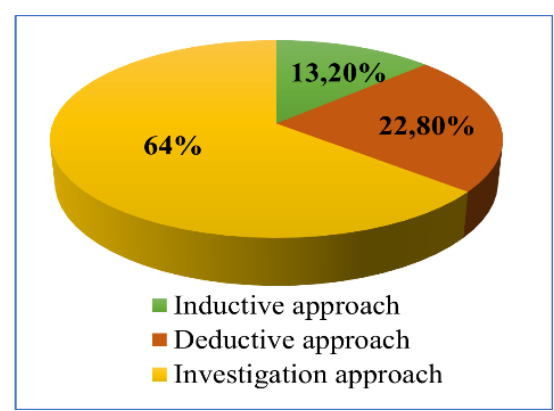

Figure 1

Pedagogical approaches

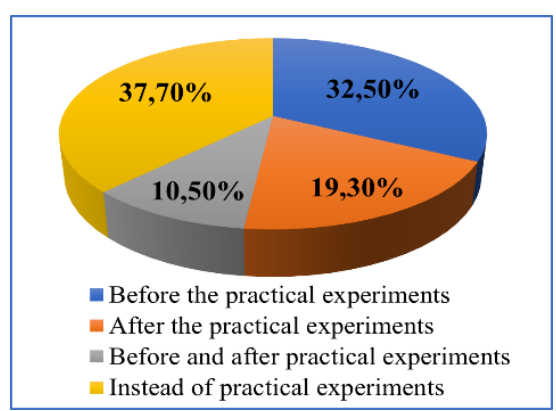

Figure 2

Timing of simulation use 
Table 2 and Figure 2 above show that most respondents $37.7 \%(18.4 \% \mathrm{Ph}-\mathrm{Ch} ; 19.3 \%$ LES) indicated that they use classroom simulations instead of the practical experiments programmed in the textbook, while $32.5 \%$ (22.8\% $\mathrm{Ph}-\mathrm{Ch} ; 9.7 \%$ LES) of respondents use them before doing the practical experiments, and $19.30 \%(11.4 \% \mathrm{Ph}-\mathrm{Ch} ; 7.9 \% \mathrm{LES})$ of respondents use them after practical experiments. Twelve participants $(6.1 \% \mathrm{Ph}-\mathrm{Ch}$; 4.4\% LES) used them before and after the practical experiments.

Teachers' views towards the use of simulations in teaching and their effect on student learning.

Table 3 below presents teachers' views on the use of simulations in the classroom. It shows that many respondents $(77.2 \%)$ slightly agreed or strongly agreed or agreed that they use simulations in teaching to help students effectively understand scientific concepts and changing events. In addition, most participants $(71.9 \%)$ Slightly agreed or strongly agreed or agreed that they use simulations in teaching to improve students' understanding of an experimental process and to meet next generation scientific standards, almost $74.7 \%$ of respondents slightly agreed or strongly agreed or agreed that they use simulations in teaching to improve students' learning activities. On the other hand, most respondents $67.5 \%$ either slightly agree or strongly agree or agree that they use simulations in teaching to teach the results of experimental work.

Table 3

Use of simulations in teaching

\begin{tabular}{|c|c|c|c|c|c|c|c|c|}
\hline \multirow{3}{*}{$\begin{array}{l}\text { Cronbach's Alpha } \\
.957\end{array}$} & \multicolumn{6}{|c|}{ Number of items } & \multirow{4}{*}{$\sum_{\Sigma}^{\Xi}$} & \multirow{4}{*}{ 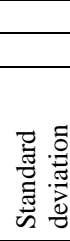 } \\
\hline & & & 6 & & & & & \\
\hline & 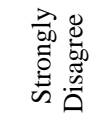 & 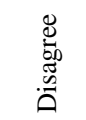 & 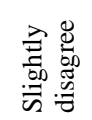 & 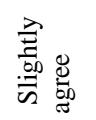 & 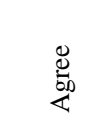 & 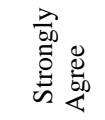 & & \\
\hline & \multicolumn{6}{|c|}{ Frequency and Percentage $(\%)$} & & \\
\hline $\begin{array}{l}\text { 1-I use simulations in my class to } \\
\text { help students understand changing } \\
\text { events. }\end{array}$ & $\begin{array}{l}15 \\
13,2 \%\end{array}$ & $\begin{array}{l}6 \\
5,3 \%\end{array}$ & $\begin{array}{l}5 \\
4,4 \%\end{array}$ & $\begin{array}{l}11 \\
9,6 \%\end{array}$ & $\begin{array}{l}46 \\
40,4 \%\end{array}$ & $\begin{array}{l}31 \\
27,2 \%\end{array}$ & 4,40 & 1,671 \\
\hline $\begin{array}{l}\text { 2-I use simulations in my class to } \\
\text { help students effectively } \\
\text { understand scientific concepts. }\end{array}$ & $\begin{array}{l}15 \\
13,2 \%\end{array}$ & $\begin{array}{l}7 \\
6,1 \%\end{array}$ & $\begin{array}{l}4 \\
3,5 \%\end{array}$ & $\begin{array}{l}10 \\
8,8 \%\end{array}$ & $\begin{array}{l}43 \\
37,7 \%\end{array}$ & $\begin{array}{l}35 \\
30,7 \%\end{array}$ & 4,44 & 1,704 \\
\hline $\begin{array}{l}\text { 3-I use simulations to improve the } \\
\text { learning activities of my students }\end{array}$ & $\begin{array}{l}15 \\
13,2 \%\end{array}$ & $\begin{array}{l}7 \\
6,1 \%\end{array}$ & $\begin{array}{l}7 \\
6,1 \%\end{array}$ & $\begin{array}{l}5 \\
4,4 \%\end{array}$ & $\begin{array}{l}39 \\
34,2 \%\end{array}$ & $\begin{array}{l}41 \\
36,0 \%\end{array}$ & 4,48 & 1,751 \\
\hline $\begin{array}{l}\text { 4-I use simulations in my lessons } \\
\text { to meet next generation scientific } \\
\text { standards }\end{array}$ & $\begin{array}{l}10 \\
8,8 \%\end{array}$ & $\begin{array}{l}11 \\
9,6 \%\end{array}$ & $\begin{array}{l}11 \\
9,6 \%\end{array}$ & $\begin{array}{l}14 \\
12,3 \%\end{array}$ & $\begin{array}{l}42 \\
36,8 \%\end{array}$ & $\begin{array}{l}26 \\
22,8 \%\end{array}$ & 4,27 & 1,581 \\
\hline $\begin{array}{l}\text { 5-I use simulations to teach the } \\
\text { results of experimental work. }\end{array}$ & $\begin{array}{ll}13 \\
11,4 \%\end{array}$ & $\begin{array}{l}17 \\
14,4 \% \\
\end{array}$ & $\begin{array}{l}7 \\
14,4 \% \\
\end{array}$ & $\begin{array}{l}11 \\
9,6 \%\end{array}$ & $\begin{array}{l}36 \\
31,6 \%\end{array}$ & $\begin{array}{l}30 \\
26,3 \%\end{array}$ & 4,14 & 1,749 \\
\hline $\begin{array}{l}\text { 6-I use simulations to improve } \\
\text { students' understanding of an } \\
\text { experimental process. }\end{array}$ & $\begin{array}{l}13 \\
11,4 \%\end{array}$ & $\begin{array}{l}13 \\
11,4 \%\end{array}$ & $\begin{array}{l}6 \\
5,3 \%\end{array}$ & $\begin{array}{l}10 \\
8,8 \%\end{array}$ & $\begin{array}{l}39 \\
34,2 \%\end{array}$ & $\begin{array}{l}33 \\
28,9 \%\end{array}$ & 4,30 & 1,724 \\
\hline
\end{tabular}

The results in Table 3 showed that most participants (over $73.4 \%$ ) chose "Slightly agree" or "Strongly agree" or "Agree" as their response on all items, while (11.86 \%) chose "Strongly disagree". Among all items, the highest mean was item 3 (I use 
simulations to improve the learning activities of my students) $(\mathrm{M}=4.48 ; \mathrm{SD}=1.751)$ followed by item 2 (I use simulations in my class to help students effectively understand scientific concepts) $(\mathrm{M}=4.44 ; \mathrm{SD}=1.704)$. On the other hand, the lowest mean was item 5 (I use simulations to teach the results of experimental work). $(\mathrm{M}=4.14$; $\mathrm{AND}=$ 1.749).

Table 4

Effects of interactive simulations on student learning in science

\begin{tabular}{|c|c|c|c|c|c|c|c|c|}
\hline Cronbach's Alpha & & & Number of & items & & & \multirow{4}{*}{ 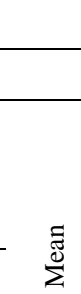 } & \multirow{4}{*}{ 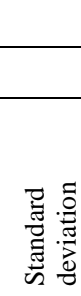 } \\
\hline .953 & & & 6 & & & & & \\
\hline & 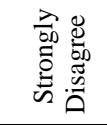 & 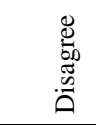 & 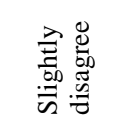 & 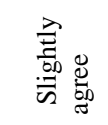 & 兽 & 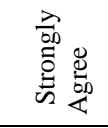 & & \\
\hline & \multicolumn{6}{|c|}{ Frequency and Percentage $(\%)$} & & \\
\hline $\begin{array}{l}\text { 1- Simulations help my } \\
\text { students to concretize } \\
\text { what they learn in class }\end{array}$ & $\begin{array}{l}13 \\
11,4 \%\end{array}$ & $\begin{array}{l}4 \\
3,5 \%\end{array}$ & $\begin{array}{l}5 \\
4,4 \%\end{array}$ & $\begin{array}{l}16 \\
14,0 \%\end{array}$ & $\begin{array}{l}49 \\
43,0 \%\end{array}$ & $\begin{array}{l}27 \\
23,7 \%\end{array}$ & 4,45 & 1,552 \\
\hline $\begin{array}{l}\text { 2- Simulations help my } \\
\text { students to reflect on } \\
\text { scientific phenomena }\end{array}$ & $\begin{array}{l}14 \\
12,3 \%\end{array}$ & $\begin{array}{l}3 \\
2,6 \%\end{array}$ & $\begin{array}{l}5 \\
4,4 \%\end{array}$ & $\begin{array}{l}14 \\
12,3 \%\end{array}$ & $\begin{array}{l}52 \\
45,6 \%\end{array}$ & $\begin{array}{l}26 \\
22,8 \%\end{array}$ & 4,45 & 1,563 \\
\hline $\begin{array}{l}\text { 3-The simulations offer } \\
\text { my students the } \\
\text { opportunity to make } \\
\text { judgments about } \\
\text { different aspects of } \\
\text { scientific phenomena. }\end{array}$ & $\begin{array}{l}13 \\
11,4 \%\end{array}$ & $\begin{array}{l}7 \\
6,1 \%\end{array}$ & $\begin{array}{l}5 \\
4,4 \%\end{array}$ & $\begin{array}{l}22 \\
19,3 \%\end{array}$ & $\begin{array}{l}40 \\
35,1 \%\end{array}$ & $\begin{array}{l}27 \\
23,7 \%\end{array}$ & 4,32 & 1,593 \\
\hline $\begin{array}{l}\text { 4- Simulations help my } \\
\text { students to visualize } \\
\text { scientific phenomena in } \\
\text { their brain }\end{array}$ & $\begin{array}{l}13 \\
11,4 \%\end{array}$ & $\begin{array}{l}4 \\
3,5 \%\end{array}$ & $\begin{array}{l}5 \\
4,4 \%\end{array}$ & $\begin{array}{l}16 \\
14,0 \%\end{array}$ & $\begin{array}{l}44 \\
38,6 \%\end{array}$ & $\begin{array}{l}32 \\
28,1 \%\end{array}$ & 4,49 & 1,581 \\
\hline $\begin{array}{l}\text { 5- Simulations motivate } \\
\text { my students to learn } \\
\text { more about scientific } \\
\text { research in the future }\end{array}$ & $\begin{array}{l}9 \\
7,9 \%\end{array}$ & $\begin{array}{l}4 \\
3,5 \%\end{array}$ & $\begin{array}{l}10 \\
8,8 \%\end{array}$ & $\begin{array}{l}12 \\
10,5 \%\end{array}$ & $\begin{array}{l}44 \\
38,6 \%\end{array}$ & $\begin{array}{l}35 \\
30,7 \%\end{array}$ & 4,61 & 1,485 \\
\hline $\begin{array}{l}\text { 6- Simulations help my } \\
\text { students improve their } \\
\text { cumulative grade point } \\
\text { average. }\end{array}$ & $\begin{array}{l}12 \\
10,5 \%\end{array}$ & $\begin{array}{l}4 \\
3,5 \%\end{array}$ & $\begin{array}{l}13 \\
11,4 \%\end{array}$ & $\begin{array}{l}18 \\
15,8 \%\end{array}$ & $\begin{array}{l}41 \\
36,0 \%\end{array}$ & $\begin{array}{l}26 \\
22,8 \%\end{array}$ & 4,32 & 1,548 \\
\hline
\end{tabular}

Table 4 above shows the effect of interactive simulations on student learning in physical science - chemistry and life and earth sciences. It shows that most respondents are aware of the goodness and usefulness of interactive simulations in education. Most respondents agreed that the use of simulations helps students concretize what they learn in class $(\mathrm{M}=$ $4.45, \mathrm{SD}=1.552)$, reflect on scientific phenomena $(\mathrm{M}=4.45, \mathrm{SD}=1.563)$ and visualize scientific phenomena in their brain $(\mathrm{M}=4.49, \mathrm{SD}=1.581)$ with a score of 92 $(80.7 \%)$ slightly agree or strongly agree. In addition, most respondents felt that the use of simulations in the classroom motivates students to learn more about scientific 
research in the future $(M=4.61 ; \mathrm{SD}=1.485)$ with a score of $91(79.8 \%)$ slightly agree or agree, or strongly agree. Then, based on the data obtained, it also shows that the use of interactive simulations in teaching provides students with the opportunity to make judgements about different aspects of scientific phenomena $(\mathrm{M}=4.32 ; \mathrm{SD}=1.593)$ with a score of $89(78.1 \%)$.

\section{Obstacles Influencing the use of interactive simulations in the classroom}

To identify the nature of the obstacles that prevent teachers from using interactive simulations in the classroom, we programmed a multiple-choice question, the answers to which are illustrated in Figure 3.

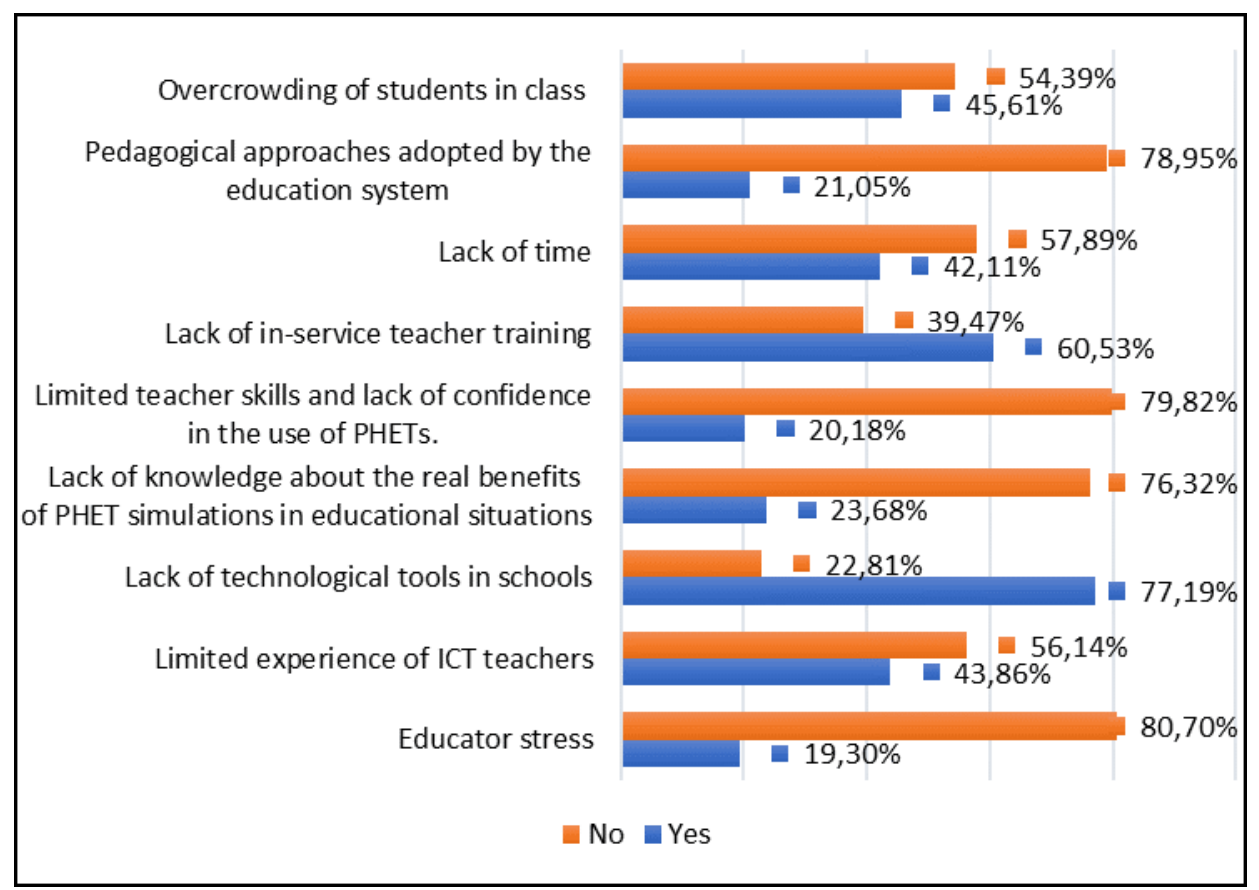

Figure 3

Obstacles influencing the use of simulations in the classroom

Based on the data provided in Figure 3 on obstacles to the use of interactive simulations, most of the physics-chemistry and life and earth sciences teachers stated that the lack of technological tools in their schools $(77.19 \%)$, lack of in-service teacher training $(60.53 \%)$ and the overcrowding of students in class $(45.61 \%)$ are the main obstacles that hinder the use of simulations in the classroom. Most teachers $(43.86 \%)$ agreed that all the ICT tools provided to their school are wasted due to their limited experience with ICT. Other teachers $(42.11 \%)$ feel that there is not enough time to use the simulations. The minority of teacher respondents stated that there is a lack of confidence regarding the use of simulations and have limited skills regarding the use of simulations $(20.18 \%)$, 
while $(21.05 \%)$ of teachers feel that the pedagogical approaches adopted by the educational system negatively influence the use of simulations and only (19.30\%) of them state that there is stress from the educator when using simulations.

\section{DISCUSSION}

The results of our study show that most of science teachers use the investigative approach when using interactive simulations in the classroom. They appear as teaching approaches aiming at the same time at the acquisition of knowledge and know-how of a technical or methodological nature. The results are consistent with the conclusions of research by (Jemaa \& Boilevin, 2016) which confirmed that a simulation-based teaching session based on the investigative approach can help students overcome their learning difficulties, and partly solve a widespread misconception problem, and that the inductive teaching method can be one of the sources of difficulties in learning scientific concepts. In addition, several international studies have shown some effectiveness of inquiry-based science education (Boilevin, 2013). Because it is based on questioning and investigation where the learner is placed at the center of the action of his learning, questions himself, acts in a reasoned manner and communicates to build his learning while being an actor in scientific activities (Darley, 2007).

Our result shows that most teachers $(37.70 \%)$ use interactive simulations in the classroom instead of the practical experiments programmed in the textbook, due to the problems of shortage of experimental materials (Chekour et al., 2015) and the delicacy of certain experiments or their dangerous characteristics. In this sense, studies (Rotimi et al., 2012; Smetana \& Bell, 2012) emphasize that simulations minimize the high cost of laboratories, shorten the duration of time-consuming experiments, provide a safe environment for dangerous experiments, and motivate students, leading to active participation. In addition, studies(Price et al., 2018; Carl E. Wieman et al., 2008) have shown that simulation adds value by allowing activities that are not possible with classroom materials, and helps overcome logistical obstacles and lack of laboratory equipment, which is consistent with our finding. Other teachers (32.5\%) use simulations before practical experiments (pre-laboratory simulation). This type of use is reasonable when the material that learners will find in the laboratory is complex and expensive, and the risk of material damage due to misuse cannot be ignored and to improve the efficiency of the laboratory equipment (Martinez-Jimenez et al., 2003; Zacharia, 2007), while some teachers $(19.30 \%)$ use it after the experiments to choose other conditions in the experiment (elimination of friction, temperature, pressure,).

The results of this study indicate that most teacher respondents believe that the use of interactive simulation can play a role in improving the quality of teaching and learning, because its use in the classroom can help students understand changing events, learn concepts more easily without getting bored and improve their understanding of the experimental process. This is due to the contribution of simulation to clarify exact things that cannot be observed with the naked eye and has helped to correct some misconceptions (Kolcak et al., 2014). It also enhances students' learning activities, and teaches the results of scientific experiments, leading to improved student achievement. This result is similar to studies (Hursen, C., \& Asiksoy, 2015) ;(Odom et al., 2010). As a 
result, teachers agreed that the use of interactive simulations is very effective in teaching science. This is consistent with various studies that have examined the effectiveness of computer simulations from different perspectives in science teaching and learning (Kotoka \& Kriek, n.d.; Zacharia, 2007).

On the other hand, our study allowed us to identify the main obstacles that hinder the effective use of simulations in teaching in Morocco. In fact, four main categories of obstacles are perceived by science teachers despite the efforts of the Ministry of National Education and Professional Training to integrate them into the learning process:

The first category of obstacles is associated with the lack of technological tools in their establishments. These results are consistent with many previous studies that have confirmed that the lack or insufficiency of technological equipment in the science room and the unavailability of computer rooms are huge constraints to the successful use of simulation (Mahdi \& Laafou, Mohamed.R, 2018; Taoufik et al., 2016). The second obstacle are the problems related to the pedagogical approaches adopted by the educational system, in particularly, the overcrowding of students in class can make it difficult to use interactive simulations. The third is linked to teachers who do not have enough time to use the simulations in the classroom, which means that there is no free time for teachers to at least use the simulations for an effective teaching and learning process. The fourth obstacle is that ICT teachers have limited experience and a lack of knowledge about the real benefits of simulations in educational situations due to the lack of in-service training.

To overcome these obstacles that discourage teachers from using interactive PhET simulations, the Ministry must:

Firstly, provide educational institutions' laboratories with computer hardware, textbook program software and interactive simulation software for teachers to use in learning and developing learners' knowledge and skills, developing programs to ensure the introduction of ICT and interactive PhET simulations in science education.

Secondly, it must improve the talents, skills, and qualifications of science teachers through continuous distance learning on the use of ICT and more specifically the use of interactive PhET simulations in the classroom.

Lastly, the ministry must train student teachers in regional education and training centers in the use and application of software in teaching and educate them on the importance of interactive simulations and its benefits for the educational process.

\section{CONCLUSION}

The results of this research show that interactive simulations such as PhET are flexible and very effective tools, as indicated by the positive views expressed by the responding science teachers. The research clearly showed that science teachers (Physics-Chemistry, Life and Earth science) use simulations through the investigative approach in the classroom to support a wide range of pedagogical objectives, and to help students develop their understanding and engagement in the scientific process. On the other hand, 
the integration of simulations into science education will also lead to tremendous success and benefits for teachers and students. However, there are several obstacles to the effective use of interactive simulations in the classroom. Our research also found that the lack of technological tools, the lack of in-service training, and problems related to the educational system's pedagogical approaches were major obstacles influencing Moroccan teachers' motivation to use interactive simulations in the classroom.

Therefore, these obstacles must be reconsidered if the competent authorities of the Ministry of Higher Education, Scientific Research and Executive Training wish to motivate teachers to use interactive simulations to improve the teaching-learning process, as the role of teachers is the key role in the effective and successful implementation of any new policy.

\section{IMPLICATIONS}

Our research may also encourage science teachers to use interactive simulations in their classrooms, as many respondents mentioned that the use of simulations can enhance learning activities in classrooms, helping students to effectively understand science concepts. The results of this research may become a precursor to larger-scale research, with the goal of better understanding teachers' views on the integration of interactive simulations into the curriculum.

The study clearly shows that science teachers who have prior knowledge of simulation may have a better chance of including it in their teaching because they have a positive view of including it in the curriculum. This result suggests the possibility of further research. The research results may encourage the relevant authorities of the Ministry of Higher Education and Scientific Research to adopt the interactive simulations learning strategy in science education, so that students acquire higher skills such as analysis, installation and evaluation ability, scientific research, discovery, and problem solving.

\section{LIMITTATION AND FUTURE WORK}

It should be mentioned that there are some limitations to this research. First, we conducted this survey with 114 teachers (of physics-chemistry and life and earth sciences) from the public schools in Morocco. In order to obtain better conclusions, it would be advantageous to conduct similar research in different disciplines (mathematics and technology) with large numbers of participants and with teachers from other levels (e.g., primary education and university). Second, teachers' views were determined through questionnaires without being corroborated by interviews and classroom observations. Follow-up discussions with participants around the questionnaire results or open-ended interviews with some respondents who completed the survey also provide rich data on teachers' views on the use and effectiveness of interactive simulations. In addition, in this research, we addressed the questionnaire to teachers who have used interactive simulations. Therefore, the views expressed by the participants in this research do not necessarily reflect the feelings and views of teachers who have not used the simulations. 
Future research in this domain should use more sophisticated instruments to provide a rich set of data on the importance of using interactive simulations. Thus, it is very important to identify and study all possible factors that influence teachers' use of simulations.

\section{DATA AVAILABILITY}

The data used to support the findings of this study are available from the corresponding author upon request.

\section{CONFLICTS OF INTEREST}

The authors declare that there are no conflicts of interest regarding the publication of this paper.

\section{FUNDING STATEMENT}

The authors received no funding for this research.

\section{ACKNOWLEDGEMENTS}

Special thanks to all the teachers who took the time to complete the questionnaire.

\section{REFERENCES}

Astutik, S., \& Prahani, B. K. (2018). The practicality and effectiveness of Collaborative Creativity Learning (CCL) model by using PhET simulation to increase students' scientific creativity. International Journal of Instruction, 11(4), 409-424. https://doi.org/10.12973/iji.2018.11426a

Bell, R. L., \& Smetana, L. K. (2008). Using Computer Simulations to Enhance Science Teaching and Learning. Technology in the Secondary Science Classroom, National Science Teachers Association, July, 23-32.

Ben Ouahi, M., Ait Hou, M., Bliya, A., Hassouni, T., \& Al Ibrahmi, E. M. (2021). The Effect of Using Computer Simulation on Students' Performance in Teaching and Learning Physics: Are There Any Gender and Area Gaps? Education Research International, 2021, 6646017. https://doi.org/10.1155/2021/6646017

Bo, W. V., Fulmer, G. W., Lee, C. K. E., \& Chen, V. D. T. (2018). How Do Secondary Science Teachers Perceive the Use of Interactive Simulations? The Affordance in Singapore Context. Journal of Science Education and Technology, 27(6), 550-565. https://doi.org/10.1007/s10956-018-9744-2

Boilevin, J.-M. (2013). Rénovation de l'enseignement des sciences physiques et formation des enseignants: regards didactiques. De Boeck Superieur.

Chekour, M., Laafou, M., \& Janati-Idrissi, R. (2015). Les facteurs influençant l'acquisition des concepts en électricité. Cas Des Lycéens Marocains Adjectif En Ligne. http://www.adjectif.net/spip/spip.php?article354

CSEFRS. (2015). Vision stratégique de la réforme 2015-2030. 
http://www.men.gov.ma/Fr/Documents/Vision_strateg_CSEF16004fr.pdf

Darley, B. (2007). La démarche d'investigation et son vocabulaire. IUFM d'aquitaine et DAESL Université Bordeaux2. Publié dans Grand $N n^{\circ} 79$ (pp. 99-111). 99-111. http://pedagogie-nord.ac-lille.fr/rpc/sciences/docs/1references/demarche-investigationvocabulaire.pdf

Dega, B. G., Kriek, J., \& Mogese, T. F. (2013). Students' conceptual change in electricity and magnetism using simulations: A comparison of cognitive perturbation and cognitive conflict. Journal of Research in Science Teaching, 50(6), 677-698. https://doi.org/10.1002/tea.21096

Droui, M., \& El Hajjami, A. (2014). Simulations informatiques en enseignement des sciences: apports et limites. Epinet: Revue Électronique de l'EPI, 1-17. http://www.epi.asso.fr/revue/articles/a1404e.htm

Erdem, A. (2019). A Study on Teachers' Views on the Use of Technology to Improve Physics Education in High Schools $\square . \quad 7(4), \quad 142-153$. https://doi.org/10.11114/jets.v7i4.4019

Ghavifekr, S., \& Rosdy, W. A. W. (2015). Teaching and learning with technology: Effectiveness of ICT integration in schools. International Journal of Research in Education and Science, 1(2), 175-191. https://doi.org/10.21890/ijres.23596

Hursen, C., \& Asiksoy, G. (2015). The effect of simulation methods in teaching physics on students' academic success. World Journal on Educational Technology, 7(1), 8798. https://doi.org/https://doi.org/10.18844/wjet.v7i1.26

Jemaa, A. Ben, \& Boilevin, J.-M. (2016). Impact de la démarche d'investigation par simulation des ondes mécaniques sur le raisonnement des élèves. 9e Rencontres Scientifiques de l'ARDiST, March. https://hal.archives-ouvertes.fr/hal-02531686

K, B. (2017). INTEGRATING PhET TOOLS IN CONSTRUCTIVIST PHYSICS. IManager's Journal of Educational Technology, 13(4), 50-55.

Kolcak, D. Y., Mogol, S., \& Ünsal, Y. (2014). A comparison of the effects of laboratory method and computer simulations to avoid misconceptions in physics education. Egitim ve Bilim, 39(175).

Kotoka, J., \& Kriek, J. (n.d.). African Journal of Research in Mathematics, Science and Technology Education The Impact of Computer Simulations as Interactive Demonstration Tools on the Performance of Grade 11 Learners in Electromagnetism. October 2014, 37-41. https://doi.org/10.1080/10288457.2014.884263

Lavoie, D. R., \& Good, R. (1988). The nature and use of prediction skills in a biological computer simulation. Journal of Research in Science Teaching, 25(5), 335-360. https://doi.org/https://doi.org/10.1002/tea.3660250503

Mahdi, K., \& Laafou, Mohamed.R, J.-I. (2018). The impact of continuous distance training on teachers of physics in computer simulation software. Journal for Educators, 
Teachers and Trainers, 9(1), 27-41. http://www.ugr.es/ jett/index.php

Martinez-Jimenez, P., Pontes-Pedrajas, A., Polo, J., \& Climent-Bellido, M. S. (2003). Learning in chemistry with virtual laboratories. Journal of Chemical Education, 80(3), 346-352. https://doi.org/https://doi.org/10.1021/ed080p346

Mastafi, M. (2013). Intégration et usages des TIC dans le système éducatif marocain: attitudes des enseignants de l'enseignement primaire et secondaire, April 2013. Adjectif.Net, 1-7. http://www.adjectif.net/spip/spip.php?article228

MEN. (2002). Charte Nationale d'Éducation et de Formation. https://www.men.gov.ma/Fr/Pages/CNEF.aspx

Moore, E. B., Herzog, T. A., \& Perkins, K. K. (2013). Interactive simulations as implicit support for guided-inquiry. Chemistry Education Research and Practice, 14(3), 257268. https://doi.org/10.1039/C3RP20157K

Nafidi, Y., Alami, A., Zaki, M., El Batri, B., \& Afkar, H. (2018). Impacts of the use of a digital simulation in learning Earth sciences (The case of relative dating in High School). Journal of Turkish Science Education, 15(1), 89-108. https://doi.org/https://doi:10.12973/tused.10223a

Ndihokubwayo, K. (2017). Investigating the status and barriers of science laboratory activities in Rwandan teacher training colleges towards improvisation practice. 4(1), $47-54$.

Odom, A. L., Marszalek, J. M., Elizabeth, R., \& Wrobel, J. M. (2010). International Journal of Science Computers and Traditional Teaching Practices : Factors influencing middle level students' science achievement and attitudes about science. January 2015, 37-41. https://doi.org/10.1080/09500693.2010.543437

Perkins, K. K., Moore, E., \& Chasteen, S. V. (2015). Examining the Use of PhET Interactive Simulations in US College and High School Classrooms. 1, 207-210. https://doi.org/10.1119/perc.2014.pr.048

Perkins, K., Moore, E., Podolefsky, N., Lancaster, K., \& Denison, C. (2012). Towards research-based strategies for using PhET simulations in middle school physical science $\begin{array}{lllll}\text { classes. } & \text { AIP } \quad \text { Conference } & \text { Proceedings, } & \text { 1413, } 298 .\end{array}$ https://doi.org/10.1063/1.3680053

Price, A. M., Perkins, K. K., Holmes, N. G., \& Wieman, C. E. (2018). How and why do high school teachers use PhET interactive simulations? Physics Education Research Conference Proceedings, 2018. https://doi.org/10.1119/perc.2018.pr.price

Proctor, R. J., Finger, G., Cavanagh, R., \& Fitzgerald, R. (2013). Development of the TTF TPACK Survey Instrument Introduction - The TTF Project and TPACK. 27(3), 2635.

Roschelle, J. M., Pea, R. D., Hoadley, C. M., Gordin, D. N., \& Means, B. M. (2000). Changing how and what children learn in school with computer-based technologies. The 
Future of Children, 10(2), 76-101. https://doi.org/10.2307/1602690

Rotimi, C. O., Ajogbeje, O. J., \& Akeju, O. O. S. (2012). A New Kind of Visual-Model Instructional Strategy in Physics. Group, 28-32. http://ijpce.org/index.php/IJPCE/article/view/106

Rutten, N., Van Joolingen, W. R., \& Van Der Veen, J. T. (2012). The learning effects of computer simulations in science education. Computers and Education, 58(1), 136-153. https://doi.org/10.1016/j.compedu.2011.07.017

Sinulingga, P., Hartanto, T. J., \& Santoso, B. (2016). Implementasi Pembelajaran Fisika Berbantuan Media Simulasi PhET untuk Meningkatkan Hasil Belajar Siswa Pada Materi Listrik Dinamis. Jurnal Penelitian \& Pengembangan Pendidikan Fisika, 2(1), 57-64. https://doi.org/10.21009/1.02109

Smetana, L. K., \& Bell, R. L. (2012). Computer Simulations to Support Science Instruction and Learning: A critical review of the literature. International Journal of Science Education, 34(9), 1337-1370. https://doi.org/10.1080/09500693.2011.605182

Stéphane, Y., \& Ze, N. (2018). La motivation à apprendre les sciences physiques chez les élèves de $3 \mathrm{e}$ en contexte camerounais : 1' apport des simulateurs associés à un exerciseur. Frantice.Net. https://hal.archives-ouvertes.fr/hal-01804594/document

Taber, K. S. (2018). The Use of Cronbach 's Alpha When Developing and Reporting Research Instruments in Science Education. 1273-1296. https://doi.org/10.1007/s11165-016-9602-2

Taoufik, M., Abouzaid, A., \& Moufti, A. (2016). Les Activités Expérimentales Dans L'enseignement Des Sciences Physiques: Cas Des Collèges Marocains. European Scientific Journal, ESJ, 12(22), 190. https://doi.org/10.19044/esj.2016.v12n22p190

Wieman, C E, Adams, W. K., Loeblein, P., \& Perkins, K. K. (2013). Teaching Physics Using PhET Simulations. 225(2010), 48-51. https://doi.org/10.1119/1.3361987

Wieman, Carl E., Adams, W. K., \& Perkins, K. K. (2008). Physics. PhET: Simulations that enhance learning. Science, 322(5902), 682-683. https://doi.org/10.1126/science.1161948

Wieman, Carl E., \& Perkins, K. K. (2006). A powerful tool for teaching science. Nature Physics, 2(5), 290-292. https://doi.org/10.1038/nphys283

Yuliati, L., Riantoni, C., \& Mufti, N. (2018). Problem solving skills on direct current electricity through inquiry-based learning with PhET simulations. International Journal of Instruction, 11(4), 123-138. https://doi.org/10.12973/iji.2018.1149a

Zacharia, Z. C. (2007). Comparing and combining real and virtual experimentation: An effort to enhance students' conceptual understanding of electric circuits. Journal of Computer Assisted Learning, 23(2), 120-132. https://doi.org/10.1111/j.13652729.2006.00215.x 